\title{
Evolution and emplacement of Archaean terranes in the Kapisigdlit area, southern West Greenland
}

\author{
Clark R. L. Friend and Allen P. Nutman
}

In the Godthåbsfjord region, early Archaean Amitsoq gneisses are found in association with the middle Archaean Nûk gneisses (McGregor, 1973). Early models of crustal evolution in the Godthåbsfjord region suggested that the Amitsoq gneisses were reworked in a major crustal accretion-differentiation event, which was marked by the injection of the voluminous Nûk gneisses (e.g. Bridgwater et al., 1974; McGregor, 1979; Moorbath $e t$ al., 1986). This event has been interpreted as having culminated in a granulite-amphibolite facies metamorphic event at c. $2800 \mathrm{Ma}$, which outlasted all significant ductile deformation (e.g. Wells, 1979; Coe, 1980).

However, recent detailed mapping combined with U-Pb zircon dating (Friend et al., 1987; H. Baadsgaard, personal communication, 1987; P. D. Kinny, personal communication, 1987) shows that between outer Ameralik and Tre Brødre 40 to $75 \mathrm{~km}$ to the south and west of the Kapisigdlit area (fig. 1), there are three lithologically distinct terranes. These terranes were tectonically juxtaposed and then folded together under amphibolite facies conditions between $c .2750$ and $2550 \mathrm{Ma}$. The Tasiusarsuaq terrane is dominated by middle Archaean gneisses affected by c. 2800 Ma granulite facies metamorphism. The Tasiusarsuaq terrane structurally overlies the Tre Brødre terrane, which is dominated by a suite of 2800-2750 Ma granodioritic gneisses, named Ikátoq gneisses (Nutman \& Friend, in press). The Tre Brødre terrane in turn structurally overlies the Faringehavn terrane, dominated by the $>3600$ Ma Amitsoq gneisses. Unlike the overlying Tasiusarsuaq terrane, neither the Tre Brødre terrane nor the Færingehavn terrane underwent granulite facies metamorphism at $c$. 2800 Ma.

The main aim of the field work in 1987 was to see if the terranes and structural history established between outer Ameralik and Tre Brødre could be traced to the north and east into the Kapisigdlit area (fig. 1). An invaluable starting point of this work was an unpublished 1:100 000 geological map of much of the area produced from helicopter reconnaissance mapping in 1976 (Allaart et al., 1977).

\section{Terranes of the Kapisigdlit area}

Faringehavn terrane. Units of streaky, tonalitic-granodioritic gneisses, with closely-spaced irregular pegma- tite banding outcrop in the Kapisigdlit area. These gneisses are cut by abundant, locally discordant amphibolite dykes, correlated with the Ameralik dykes (McGregor, 1973), and are continuous with the type Amitsoq gneisses of the Færingehavn terrane in the outer Ameralik area. However, no units of augen granite gneiss, a common Amîtsoq lithology in the outer Ameralik region (e.g. Nutman et al., 1984), were found. The streaky Amîtsoq gneisses in the Kapisigdlit area contain inclusions of banded amphibolite, banded iron formation, and clinopyroxene-rich rocks. Collectively, these resemble the Akilia (supracrustal) association found as inclusions in the Amitsoq gneisses of the outer Ameralik area (McGregor \& Mason, 1977). The Amitsoq gneisses are not intruded by the late Archaean Ikátoq gneisses which are the dominant lithology in the adjacent Tre Brødre terrane.

Amitsoq gneisses outcrop on the north and south shores of inner Ameralik, Itivdleq and Ameragdla. However, they were not found to be as extensive as was stated by Allaart et al. (1977). Coastal work and helicopter reconnaissance failed to find either the large unit of Amîtsoq gneisses running from inner Ameragdla eastwards along the valley of Austmannadalen, or the Amîtsoq gneisses east of Kapisigdlit, both described by Allaart et al. (1977).

Tre Brødre terrane. Much of the Kapisigdlit area consists of rather homogeneous biotite \pm garnet granodioritic gneisses, with widely spaced pegmatite layering. These gneisses grade locally into rather more schlieric, heterogeneous gneisses, which in areas of poor exposure can be hard to distinguish from the Amitsoq gneisses. The granodioritic gneisses contain inclusions of homogeneous hornblende + biotite dioritic gneiss. These granodioritic and dioritic gneisses resemble, and are continuous to the south-west with, the type Ikátoq gneisses of the Tre Brødre terrane.

In the Kapisigdlit area, the Ikátoq gneisses contain abundant inclusions of garnet + biotite \pm sillimanite \pm cordierite \pm staurolite metasediment, banded amphibolite, metaquartzite, metagabbro, anorthosite and subordinate ultramafic rocks. The metasediments are locally found as inclusions in the gabbro and leucogabbro.

The metaquartzite apparently forms a single unit up to $50 \mathrm{~m}$ thick, which can be traced for many kilometres along strike, despite being intruded and disrupted by 


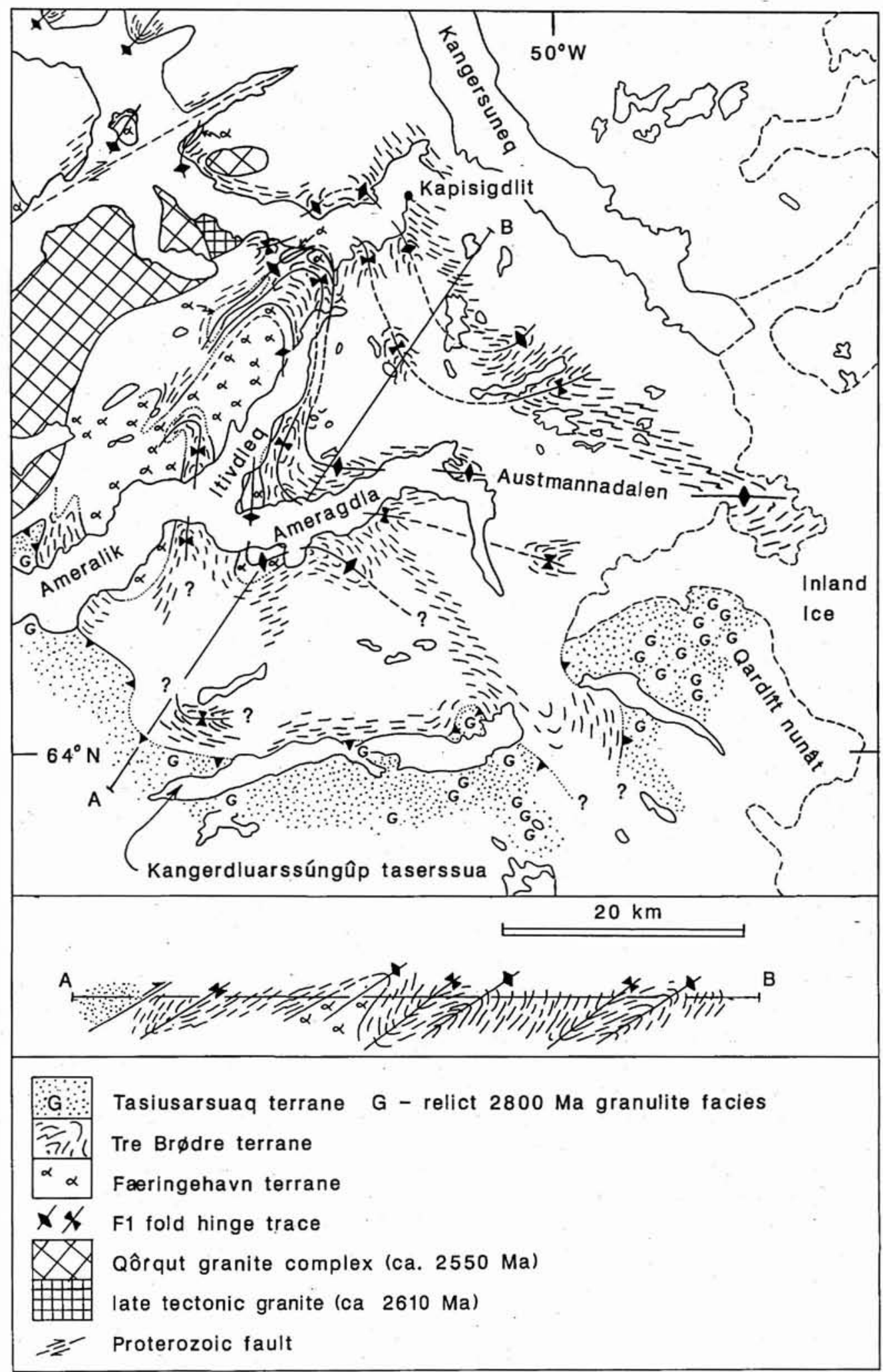

Fig. 1. Geological sketch map of the Kapisigdlit area. Blank areas not visited in 1987. Western $5 \mathrm{~km}$ of Ameralik on the figure was mapped by V. R. McGregor. 
Ikátoq gneisses. The quartzite is commonly white, and consists of quartz-rich layers a few millimetres to a few centimetres thick, separated by thin seams containing mica and opaque minerals. Locally the quartzite contains finely disseminated chromian muscovite, giving it a green colouration. Two new localities were found $\left(64^{\circ} 15^{\prime} 40^{\prime \prime} \mathrm{N}, \quad 50^{\circ} 5^{\prime} 15^{\prime \prime} \mathrm{W}\right.$ and $64^{\circ} 23^{\prime} 45^{\prime \prime} \mathrm{N}$, $50^{\circ} 1^{\prime} 5^{\prime \prime} \mathrm{W}$ ) where this colouration is sufficiently strong for the quartzite to be worked for 'greenlandite'. Previously this quartzite had been reported at only two localities $\left(64^{\circ} 20^{\prime} 20^{\prime \prime} \mathrm{N}, 50^{\circ} 10^{\prime} 50^{\prime} \mathrm{W}\right)$ in the Kapisigdlit area (found by V. R. McGregor), and on the island of Simiutâ, outer Ameralik (Nutman \& Bridgwater, 1983). Detrital zircons separated from quartzite at these localities are early Archaean in age, showing that they are derived at least in part from erosion of ancient crustal rocks, such as the Amîtsoq gneisses (P. Kinny, personal communication, 1987; Schiøtte et al., in press).

The gabbro and leucogabbro commonly show layering. This is interpreted as due to igneous structures transposed during later ductile deformation. The leucogabbros, gabbros and ultramafic rocks are interpreted as having been derived from a large stratiform intrusion at least $200 \mathrm{~m}$ thick, consisting of layered gabbro with interspersed ultramafic units at the base, followed upwards by leucogabbro with subordinate units of gabbro and anorthosite. No chromite-rich units were found in these rocks.

In the Kapisigdlit area, the Tre Brødre terrane does not contain inclusions of Amîtsoq gneisses, as seen locally in this terrane to the south-west (Friend $e t$ al., 1987).

Tasiusarsuaq terrane. The south of the area consists of polyphase, nebulitic tonalitic gneisses containing scattered inclusions of basic rocks. These rocks are continuous with the Tasiusarsuaq terrane to the south and west, affected by granulite facies metamorphism at $c$. $2800 \mathrm{Ma}$ (McGregor et al., 1986; Friend et al., 1987). In the Kapisigdlit area these nebulitic gneisses with their basic inclusions have brown-weathered patches up to $500 \mathrm{~m}$ across, with relict granulite facies assemblages. The gneisses with their basic inclusions adjacent to these patches have amphibolite facies assemblages. However, these gneisses have blebby textures attributed to recrystallisation under granulite facies conditions (McGregor et al., 1986). The blebby textures have subsequently been transposed to varying degrees during deformation as the rocks were retrogressed under amphibolite facies conditions. On the south side of Kangerdluarssúngûp taserssua (fig. 1), helicopter reconnaissance showed that granulite facies assemblages with subvertical foliation are commonly best preserved on hill tops above $1000 \mathrm{~m}$. At lower altitudes on the same hills, these granulite facies gneisses are totally retrogressed under amphibolite facies conditions, with their subvertical foliation transposed into a new southerly dipping foliation.

\section{Tectonometamorphic evolution}

Terrane boundaries. The boundaries between terranes are marked by zones, generally about $10 \mathrm{~m}$ wide, but in places up to $50 \mathrm{~m}$ wide. These zones consist of finely layered quartzo-feldspathic and quartz-rich rocks and mica and amphibole rich schistose rocks. The schistose rocks commonly contain thin disrupted pegmatite veins and feldspar grains up to $1 \mathrm{~cm}$ across, which may represent porphyroclasts. The finely layered quartzo-feldspathic rocks and quartz-rich rocks have mylonitic to ultramylonitic textures with superimposed blastomylonitic textures. By analogy with studies in the Tre Brødre area (Friend et al., 1987), these rocks are interpreted as mylonites developed during the juxtaposition (emplacement) of the three terranes.

Emplacement of terranes and folding. The cross-section (fig. 1) shows that the Færingehavn terrane is structurally lowest, and that the Tasiusarsuaq terrane, affected by granulite facies metamorphism at $2800 \mathrm{Ma}$, is structurally highest. This is the same order of stacking of terranes found in the Tre Brødre area (Friend et al., 1987), and indicates that the emplacement of the terranes must have occurred after $2800 \mathrm{Ma}$ (the age of the granulite facies) and must have involved thrusting of the Tasiusarsuaq terrane over the other two terranes. Further evidence for this comes from south of Kangerdluarssúngûp taserssua (fig. 1), where granulite facies assemblages are least retrogressed on the tops of hills.

After their tectonic juxtaposition, the Færingehavn and the Tre Brødre terranes were folded together in large, tight to isoclinal folds $\left(F_{1}\right)$. These folds were mapped by tracing the tectonic boundary between the Færingehavn and the Tre Brødre terranes, by using as structural markers large inclusion trains of metasediment, gabbro and leucogabbro in the Tre Brødre terrane, and by making extensive use of the sense of vergence of $F_{1}$ parasitic folds. Traces of the hinges of major $F_{1}$ folds are indicated on fig. 1 . The $F_{1}$ folds have associated with them a mineral lineation parallel to their hinges.

The $F_{1}$ folds seem to die away southwards towards the Tasiusarsuaq terrane, so that the boundary between the Tasiusarsuaq and the Tre Brødre terranes has a simpler outcrop pattern than the boundary between the Fxringehavn and the Tre Brødre terranes (fig. 1). To ex- 


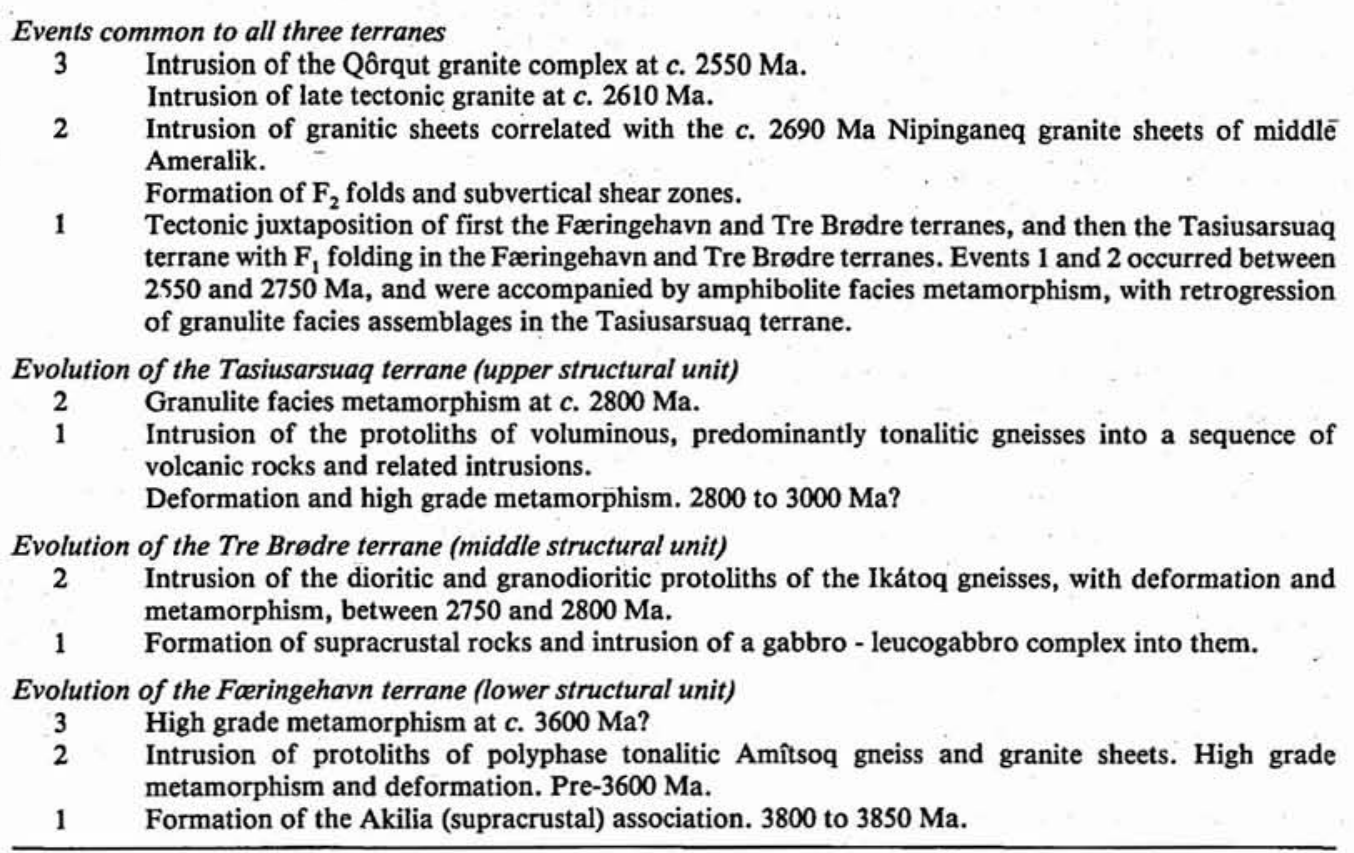

plain this, we suggest that the $F_{1}$ folds developed at structural levels below the Tasiusarsuaq terrane which acted as a rigid block as it was thrust into position. Therefore, if the Tre Brødre and Færingehavn terranes had already been emplaced by the time the Tasiusarsuaq terrane was thrust into position, their outcrop pattern would be controlled by $F_{1}$ folds. It is concluded that the Færingehavn and Tre Brødre terranes were emplaced first, and that subsequently the Tasiusarsuaq terrane was thrust into position (Table 1).

After the emplacement of all three terranes, but prior to intrusion of the c. $2550 \mathrm{Ma}$ (Baadsgaard, 1976; Moorbath et al., 1981) post-tectonic Qôrqut granite complex (fig. 1), non-cylindrical folds $\left(\mathrm{F}_{2}\right)$ developed. These folds commonly have an en echelon basin and dome form, are closed to tight, trend NNE and their axial surfaces dip to the north-west. $F_{2}$ parasitic folds are generally close to open, with the same style as the larger structures. Overprinting of $F_{2}$ folds onto $F_{1}$ folds is responsible for the complex outcrop pattern of the boundary between the Færingehavn and Tre Brødre terranes (fig. 1). $F_{2}$ structures seem to become more open and with a greater wavelength eastwards towards the Inland Ice. Mineral lineations coaxial with $F_{1}$ folds are rotated around $F_{2}$ structures (fig. 2). In the tighter $F_{2}$ structures in the west of the area, $F_{1}$ lineations are commonly rotated into near parallelism with $F_{2}$ fold hinges, giving the impression that new linear fabrics formed during the $\mathrm{F}_{2}$ event.

Metamorphism. Since the intrusion of the Ameralik dykes in the middle Archaean, the Færingehavn terrane has not been affected by granulite facies metamorphism. Likewise, the Tre Brødre terrane has never been

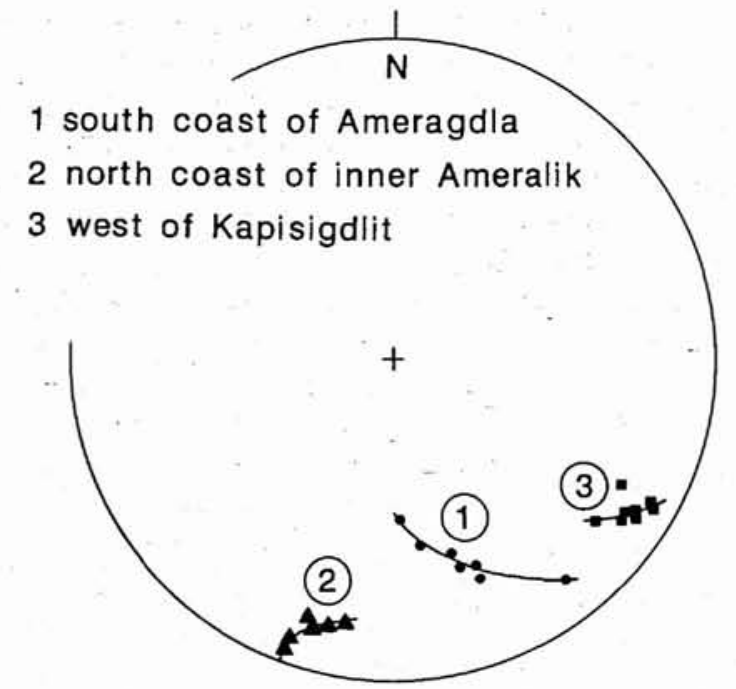

Fig. 2. Lambert equal area projection of mineral lineations parallel to $F_{1}$ fold hinges, folded around $F_{2}$ parasitic folds. 
affected by granulite facies metamorphism. Amphiboles and sillimanite that are part of the amphibolite facies assemblages of the Færingehavn and Tre Brødre terranes generally have the mineral lineation parallel to the $F_{1}$ fold hinges. On the other hand, the Tasiusarsuaq terrane contains relict c. $2800 \mathrm{Ma}$ granulite facies assemblages and amphibolite facies assemblages produced by retrogression of the granulite facies assemblages. Therefore most of the amphibolite facies assemblages in the area reflect $P, T$ conditions during emplacement of the terranes and $F_{1}$ and $F_{2}$ folding later than $2800 \mathrm{Ma}$, but before $2550 \mathrm{Ma}$ (Table 1). Simplistic models of crustal evolution such as those suggested by Wells (1979) for adjoining areas to the south, which involve a single post-tectonic metamorphic peak at $c$. $2800 \mathrm{Ma}$, cannot therefore be applied.

\section{Late Archaean granites}

Roberts (1979) described granitic sheets (Nipinganeq granites) from middle Ameralik, which give a $\mathrm{Rb}-\mathrm{Sr}$ whole rock isochron age of $c$. $2690 \mathrm{Ma}$. These sheets are commonly composite, with pegmatitic margins and foliated gneissic cores. Many of them were intruded along active shear fractures. Similar sheets of granite were found in all three terranes to the east in the Kapisigdlit area. These granitic sheets post-date emplacement of the terranes and $F_{1}$ folding,-but seem to be affected by $\mathrm{F}_{2}$ folding. To the west of Kapisigdlit village there are swarms of pale, medium to fine grained granite sheets that are very weakly deformed. They seem to post-date $\mathrm{F}_{2}$ folding. These sheets increase in abundance westwards, giving rise to the late tectonic granite (fig. 1), dated at c. 2610 Ma (C. R. L. Friend, unpublished data). Undeformed pegmatite sheets up to $10 \mathrm{~m}$ thick occur sporadically throughout the area, increasing in abundance westwards. They are correlated with the $c$. 2550 Ma Qôrqut granite complex (fig. 1). Dating of these granitic sheets provides further evidence that ductile deformation continued sporadically throughout the late Archaean with associated recrystallisation under amphibolite facies conditions, and did not cease at $c$. 2800 Ma.

\section{Discussion}

The investigation of the Kapisigdlit area supports the model of crustal evolution for the area to the south and west recently proposed by Friend et al. (1987), involving the separate evolution and then emplacement of three terranes in the late Archaean.

Acknowledgements. Vic McGregor is thanked for making reconnaissance studies in northern Godthåbsfjord possible, and for stimulating discussion of the geology. Our thanks also go to Hans Sivertsen (Epaneezer Mission in Nuuk), the staff of Grønlands Landsmuseum in Nuuk, Scott Smithson (University of Wyoming) and Roger Braithwaite (GGU) for logistic assistance, and Ole Termansen of Unifly for his skillful flying. The field season was partly financed by a grant from the Royal Society of London.

\section{References}

Allaart, J. H., Jensen, S. B., McGregor, V. R. \& Walton, B. J. 1977: Reconnaissance mapping for the 1:500 000 map sheet in the Godthåb-Isua region, southern West Greenland. Rapp. Grønlands geol. Unders. 85, 50-54.

Baadsgaard, H. 1976: Further U-Pb dates in zircons from the early Precambrian rocks of the Godthåbsfjord area, W. Greenland. Earth planet. Sci. Lett. 33, 261-267.

Bridgwater, D., McGregor, V. R. \& Myers, J. S. 1974: A horizontal tectonic regime in the Archaean of Greenland and its implications for early crustal thickening. Precambrian Res. 1, 179-197.

Coe, K. 1980: Nûk gneisses of the Buksefjorden region, southern West Greenland, and their enclaves. Precambrian Res. 11, 357-371.

Friend, C. R. L., Nutman, A. P. \& McGregor, V. R. 1987: Late-Archaean tectonics in the Færingehavn - Tre Brødre area, south of Buksefjorden, southern West Greenland. $J$. geol. Soc. Lond. 144, 369-376.

McGregor, V. R. 1973: The early Precambrian gneisses of the Godthåb district, West Greenland. Phil. Trans. roy. Soc. Lond. A 273, 343-358.

McGregor, V. R. 1979: Archaean gray gneisses and the origin of the continental crust: evidence from the Godthåb region, West Greenland. In Barker, F. (edit.). Trondhjemites, dacites and related rocks, 169-204. Amsterdam: Elsevier.

McGregor, V. R. \& Mason, B. 1977: Petrogenesis and geochemistry of metabasaltic and metasedimentary enclaves in the Amitsoq gneisses, West Greenland. Am. Miner. 62, 887904.

McGregor, V. R., Nutman, A. P. \& Friend, C. R. L. 1986: The Archaean geology of the Godthåbsfjord region, southern West Greenland. In Ashwal, L. D. (edit.) Workshop on early crustal genesis: the world's oldest rocks. Lunar and Planetary Institute Technical Report 86-04, 113-169.

Moorbath, S. Taylor, P. N. \& Goodwin, R. 1981: Origin of granitic magma by crustal mobilisation: $\mathrm{Rb}-\mathrm{Sr}$ and $\mathrm{Pb} / \mathrm{Pb}$ geochronology and isotope geochemistry of the late Archaean Qôrqut granite complex of southern West Greenland. Geochim. cosmochim. Acta 45, 1051-1060.

Moorbath, S., Taylor, P. N. \& Jones, N. W. 1986: Dating the oldest terrestrial rocks - fact and fiction. Chem. Geol. 57, 63-86.

Nutman, A. P. \& Bridgwater, D. 1983: Deposition of Malene supracrustal rocks on an Amîtsoq basement in outer Ameralik, southern West Greenland. Rapp. Grønlands geol. Unders. 112, 43-51.

Nutman, A. P. \& Friend, C. R. L. in press: Reappraisal of crustal evolution at Kangimut sammissoq, Ameralik fjord, 
southern West Greenland: fluid movement and interpretation of $\mathrm{Pb} / \mathrm{Pb}$ isotopic data. In Bridgwater, D. (edit.) Fluid movements, element transport, and the composition of the deep crust. Dordrecht: Reidel.

Nutman, A. P., Bridgwater, D. \& Fryer, B. J. 1984: The iron-rich suite from the Amîtsoq gneisses of southern West Greenland: early Archaean plutonic rocks of mixed crustal and mantle origin. Contr. Mineral. Petrol. 87, 24-34.

Roberts, I. W. N. 1979: Archaean evolution of inner Ameralik, south-west Greenland, with special reference to mid-
Archaean magmatism. Unpublished $\mathrm{Ph}$. D. thesis, Univ. Wales, Aberystwyth.

Schiøtte, L., Compston, W. \& Bridgwater, D. in press: Late Archaean ages for the deposition of clastic sediments belonging to the Malene supracrustals, southern West Greenland. Earth planet. Sci. Lett.

Wells, P. R. A. 1979: Chemical and thermal evolution of Archaean sialic crust, southern West Greenland. J. Petrol. 20, 187-226.
C. R. L. F,

Department of Geology,

Oxford Polytechnic,

Oxford $O X 3 O B P$,

England.
A. P. N., Department of Earth Sciences, Memorial University of Newfoundland, St. John's, Newfoundland, Canada $A 1 B 3 \times 5$.

\title{
Application of seismo-stratigraphic interpretation techniques to offshore West Greenland
}

\author{
James A. Chalmers
}

A pilot study is being conducted to determine if the use of seismo-stratigraphic interpretation techniques can increase the understanding of the geology of offshore West Greenland in order to reassess the prospectivity of the area.

During the period 1975 to 1979 , a number of concessions offshore West Greenland were licensed to various consortia of oil companies to search for petroleum. Some $40000 \mathrm{~km}$ of seismic data were acquired, all of which is now released. Five wells were drilled, all of them dry, and all concessions were relinquished by the industry by 1979 .

The regional geology of offshore West Greenland has been summarised by Manderscheid (1980) and Henderson et al. (1981). They show the West Greenland Basin to consist of fairly uniformly westward dipping sediments bordered near the shelf break by a basement ridge. These authors used what may be termed 'conventional' techniques of seismic interpretation. However, since that time the techniques of seismo-stratigraphy (Vail et al., 1977; Hubbard et al., 1985) have become established. They are now being applied to study seismic data acquired during the mid-1970s.

\section{Interpretation}

Concession 26, held by a group operated by Amoco Greenland, lies south-west of Færingehavn on GGU 1:100 000 base map 63 S 5130 (fig. 1). It was relin- quished during 1978 without drilling. A seismic grid of roughly $3 \times 5 \mathrm{~km}$ exists over the former concession. The data were acquired in 1975 and 1977 and are either 24or 48 -fold. None of the lines have been migrated. The

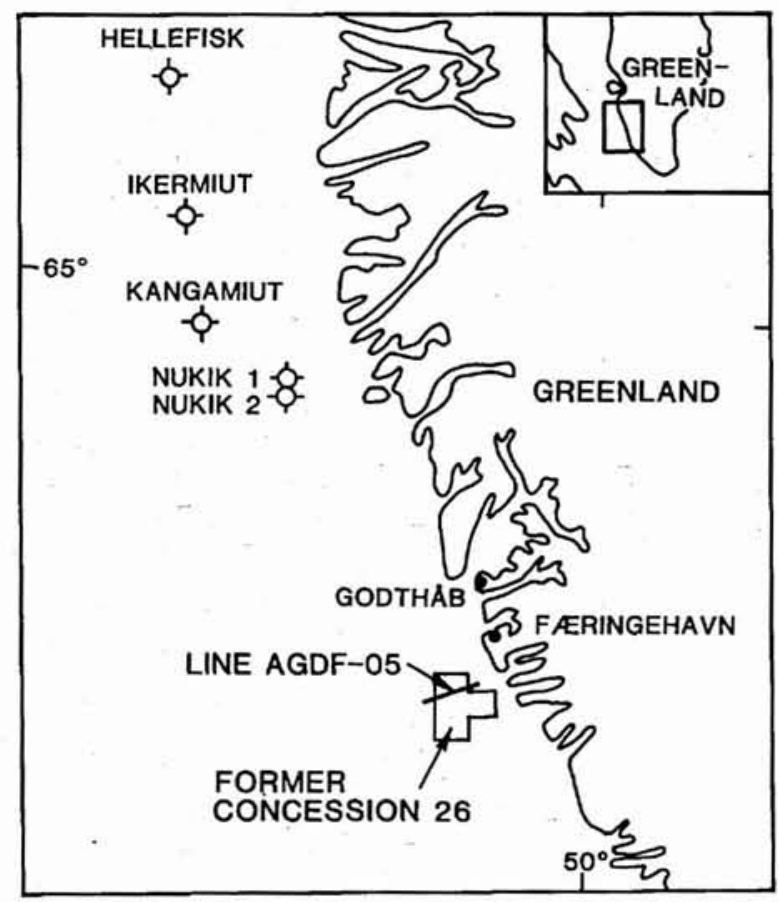

Fig. 1. Location of former concession 26 offshore West Greenland. 